\title{
Public relations for industrial archaeology
}

\author{
N. James*
}

Completion of the motorway M74's west end, through part of Glasgow and its fringe, was taken vigorously as an opportunity both to explain archaeology and local history to residents and to invite them to contribute to the study of the route. The route runs five miles across the old industrial south of the city and through the Gorbals, once the British byword for an urban 'sink'. The Discover M74 Public Archaeology Programme ran from August 2007 to February 2009, while archaeological tests and excavations were carried out and the bulldozers and pile-drivers then moved in. It engaged well over a thousand schoolchildren, various study groups and community groups, and many other local visitors. Imaginatively and effectively organised under the aegis of Transport Scotland (for the Scottish Government) and three local authorities, it has set a new standard in planning and managing public outreach.

This is becoming a prime principle in Britain. Historic Scotland, the Scottish Government's agency for managing the historic environment, runs a 'Community \& Outreach' programme. All the signs from England's corresponding body during the past ten years are that, there, the proposed Heritage Protection Reform Bill will make priorities of public access, information and consultation (see, for instance, English Heritage's current statement, in References). Yet to be worked through, however, is the relation between 'archaeology in public', on the one hand, the kind of programme undertaken for M74, where professional priorities determine what is done, and, on the other hand, 'community archaeology', in which residents contribute to the agenda. Smith \& Waterton (2009) have recently reviewed the main issues.

The project at Glasgow depended on two visions, civic, and archaeological. As with other urban road schemes, there was controversy, and it was partly on that account that Transport Scotland and the Glasgow City Council - prompted by its interdepartmental Local History \& Archaeology Strategy Working Group - were keenly alert to opportunities for education and for acknowledging residents' memories of the area affected. Assessment, by Glasgow University, of the road's likely impacts on archaeology, confirmed that industry would be the main theme; and it cited the Five Points Site, New York City, to emphasise the potential for studying housing in a notorious neighbourhood as well as the factories. Specifications for investigation were drawn up accordingly by the West of Scotland Archaeology Service and, on behalf of Transport Scotland and the local authorities, the City Council commissioned Headland Archaeology and Pre-Construct Archaeology together to run the excavations and to engage the public. The City Council then worked especially effectively to involve schools and to encourage local industrial and social history in curricula. 
By all accounts, work and housing alike were grim in the area. Yet parts of the nineteenthcentury public archives were confidently discarded a generation ago; and, by now, most who still remember the old Gorbals and the factories have dispersed, giving way to a new population. So archaeology was needed; and so was oral history; but the social change helps to explain why the Discover Programme could not have been 'community archaeology'. Standing buildings were recorded; up to a hundred professional excavators went to work; and 23 oral history interviews were recorded, mostly with former residents found in various places. There were three main excavation sites: the Caledonian Pottery; a foundry and housing at the Govan Iron Works ('Dixon's Blazes'); and dwellings between Eglinton Street and Pollokshaws Road. Limited results were obtained at six factories and some housing on or near Scotland Street and from a sample of the Glasgow, Paisley \& Johnstone Canal. The interviews and other chats added context - and some pathos - to rather bare traces of housing and helped to explain features easily misconstrued on the archaeological evidence alone. The research must have been haunting; but now the massive, arbitrary-looking roadworks cast the streets and buddleia-festooned walls in elegiac light.

The Discover Programme had three aspects. It was based at the Dig Discovery Centre; there was a series of special events; and substantial resources were put online.

The Discovery Centre was at the Scotland Street School Museum, which occupies a school of stunning design by Charles Rennie Mackintosh. There were two modest but effective exhibitions of the archaeologists' findings and equipment, supplemented by models and paintings lent by the Glasgow Museums service and by videos of the excavations and of the oral history. Next door was shown a good film about the excavations. In the foyer were terminals for internet access and a large collection of copies from archives about the archaeological sites. Little 'simulated digs' showed participants how we discover features and recover finds of successive periods (but the rubber 'soil' stipulated for 'health \& safety' limited illustration of stratigraphy). Visitors were invited to design the kind of tiles that decorated the 'better sort' of workers' housing a century ago. The 'sim digs' and probably the tiling were inspired by the York Archaeological Trust. The Centre also made up boxes of unstratified finds for schools and for talks or other events.

There were open days at the main excavation sites and explanatory boards encouraged visitors to look in. From a huge dump at the Caledonian Pottery, the team gave spoiled pots away (with the Scottish Finds Allocation Panel's permission). There was a day conference (free of charge) to announce results; and there were introductory classes for adults on surveying and drawing, environmental archaeology, identifying finds, recording buildings, and oral history. Children were encouraged too, with activities such as 'Archaeological detectives' and 'adventures', and projects in art and music.

Lots of material was placed on Transport Scotland's and the Glasgow Museums service's internet sites (see References), including summaries of the excavations' results, the original evaluations and 'desktop' study, archives on the sites, ten of the oral history interviews, and background on history. There is also a link to the site of a team of pupils who helped the research.

Once the Programme is reviewed, there should be plenty to say in regard to the local sense of place or belonging, to the appreciation of archaeology, and to which techniques worked well or which less so. It showed the importance of planning, and the active support of local 
leaders. Although the prospects for other such large projects look dim at present, once, eventually, work recovers, 'Community \& Outreach' will probably be a common priority. How will it be funded; and is outreach too much for busy archaeologists to manage without 'animateurs' or interpreters? How are participants' responses to be assessed; and what is to be made of one informant's refusal, in Glasgow, to discuss his memory? Since the M74 project was not 'community archaeology', the issue about compatibility of lay knowledge and values with archaeologists' remained implicit.

A new goal for the future should be to excite more adults as well as children. Some of the informants in Glasgow were surprised that we value what they know. That kind of surprise can be very fruitful; and so can be the surprises awaiting archaeologists and historians enabled to consult the public more widely.

\section{Acknowledgements}

Russel Coleman (Headland Archaeology), Hugh McBrien (West of Scotland Archaeology Service) and David Walker (M74 Dig Oral History Project) helped generously to explain the project. I benefitted from a discussion of issues with John Etté; and, for their attentive comments on a draft of this note, I am most grateful to Mr McBrien, Dr Walker, Alan Anderson (Glasgow City Council), Rod McCullagh (Historic Scotland) and Madeleine Hummler; but the blame for any errors here is mine.

\section{References}

English Heritage. http://www.english-heritage.org.uk/ server/show/nav.8380 (accessed February 2009).

Glasgow Museums. http://www.glasgowmuseums.com/ venue/showExhibition.cfm? venueid=12\&itemid $=210$ (accessed February 2009).
SMith, L. \& E. WATERTON. 2009. Heritage, communities and archaeology. London: Duckworth.

Transport Scotland. http://www.transportscotland.gov. $\mathrm{uk} /$ projects/m74-completion/m74-dig (accessed February 2009). 